\author{
Article Type: Research Article \\ Year: $2020 \quad$ V/I: 6(1) \\ Pages: $17-31$ \\ Corresponding Author: Olcay Y1lmaz / tr.olcay@gmail.com \\ DOI: http://dx.doi.org/10.19148/ijhbs.669299 \\ Citation Information: \\ Yilmaz, O. \& Ergene T. (2020). Visualizing Career Orientations of College Students on a \\ Standard Educational Classification System. The International Journal of Human and \\ Behavioral Science, 6(1), 1-20. doi: 10.19148/ijhbs.669299
}

Received: 02/01/2020

Accepted: 15/06/2020

Published: 26/08/2020

\title{
Visualizing Career Orientations of College Students on a Standard Educational Classification System
}

\author{
Olcay Y1lmaz, TED University Faculty of Education, Turkey \\ ORCID: https://orcid.org/0000-0003-4740-3782
}

Tuncay Ergene, Hacettepe University Faculty of Education, Turkey ORCID: https://orcid.org/0000-0003-1684-9378

\begin{abstract}
In this research it is aimed to present a visual comparison of career orientations of college students using ISCED (International Standard Classification of Education) classification system. Research sample consisted of seven experts and 529 college students from 10 different majors of ISCED broad domains. Data was collected with a survey developed by researcher and Personal Globe Inventory - Short Form (Tracey, 2010). Expert opinions were used to locate 26 ISCED narrow educational fields in the light of vocational interest and competence scores. Multi-Dimensional Scaling was used with data obtained from Personal Globe Inventory - Short Form to determine college majors' positions. Most of the college majors were mapped in theoretically congruent positions, yet some discrepancies were found, especially in Conventional and Realistic types. When competence belief placements on dimensions were inspected there found some significant differences in comparison with their interest locations. These differences between interests and competence beliefs highlight the importance of a holistic evaluation when choosing a college major instead of stressing just one important factor. It might be interpreted that interests and abilities are still not the major determinants when deciding a college major and current environmental models scarcely match with the theoretical explanations.
\end{abstract}

Keywords: Vocational choice, interests, competencies, Holland, ISCED

\section{Introduction}

Vocational choices are being made to a large extent depending on some assessment results and circumferential obligations. Even coincidence has a major role since there is a lack of systematic and effective vocational guidance and career counseling support. As it is evidently known, when individuals work in an unintentionally, non-systemic or coincidentally chosen vocation, they do not feel satisfied and usually change their vocations; therefore, problems such as reluctance to work and low productivity, not following professional innovations are brought about. These problems affect the working enterprise, the sector and the country's economy in a negative way, reducing the occupational and life satisfaction of individuals; it weakens national and international competitive power (Akkök \& Watts, 2006).

These problems, which are experienced while making a career decision, also affect young people's career significantly. Educated young people in Turkey have difficulty finding job. Along with 
high unemployment rates, this rate is even higher, especially for young people (World Bank, 2015). At this point, with factors such as economic conditions and employment opportunities, there seems to be a need to question the professional choices made in entering the higher education system.

The purpose of professional decision making in career counseling which may be a framework that can be a solution to the problem, is to present the options appropriate to the type of the person. In this case, it is assumed that job satisfaction and success will increase (Tracey \& Gupta, 2008). Research has shown that individuals are much more productive when there is a good level of fit between their personality typologies and environmental characteristics. The mismatch between the type of personality and the environment causes dissatisfaction, unbalanced career orientations and poor performance (Holland, 1974, 1996).

As a consequence of the transition of higher education graduates from school to business life, unemployment in the young population is accompanied by school dropouts (EU, 2011). Over the years, a number of public regulations have begun to be implemented towards this negative picture emerging in higher education. For example, in the 10th National Development Plan (DPT, 2014, p.32), attention was drawn to the problems between education and employment and in this regard it is stated that "The secondary education and higher education transition system can be made a process-oriented evaluation with the support of effective guidance and guidance services that take into account the interests and abilities of students".

As long as there is an academic field that is congruent with a student's personality, and the content of the courses is similar to the working environment with their professional lives, the satisfaction for that area is also higher (Feldman, Ethington, \& Smart., 2001). Along with the level of satisfaction, the congruency between the measured vocational interests and the major is also a predictor of academic performance (see Tracey \& Robbins, 2006). The choice of academic field is influenced by the students' interest patterns and in many researches Holland's personality typology (1997), which is widely used in career counseling, has been shown to be a predictor of the academic major (Miller, 2010; Porter \& Umbach, 2006).

Although there are many measurement tools for self-exploration which is a component of personvocational environment congruence, their interpretation is based on subjective evaluations. The norms used in the evaluation of the measurement tools were determined according to the characteristics of a limited sample (Özyürek, 2013). When it is thought of as a career information system, it is necessary to know what career assessment scores mean to use, and how to interpret such a system easily while it is useful to have it integrated with the educational system. In the case of individual, vocational and educational environment congruence, it can be considered that the determination of environmental characteristics can help in this respect. According to Miller (1994) personalities of the individuals of the same occupation are similar and individuals tend to choose college majors or vocational environments that are congruent with their personality orientation.

Parallel to this point of view, the environmental characteristics of the academic major that a student participates in is largely in accordance with individuals who are dominated by certain personality types. In such a university environment, the dominant skills in the educational environment are unique to the study world that education requires. As a result, academic programs are environments where similar types of personality dominate because people and environments are inseparable entities (see Feldman et al., 2001). For example, it is expected that people in the social environment will have the characteristics of the social type.

In this research, which is based on Holland's theory (1997) about the vocational selection of individuals and their career orientations, it is aimed to develop a method that facilitates the 
interpretation of interest and competence profiles of the students. In this context, it is aimed to create a visualization method that integrates Holland's personality types and the broad fields of education and in the International Standard Classification of Education (ISCED) system. With such a mapping system in which the interests and competence of the clients and the educational fields are in relation to these two variables, clients will be able to gain an awareness by comparing their competence with their interests and also be able to distinguish any possible contradiction.

Although Holland's theory (1997) is one of the most important and influential theories in career counseling, the environmental aspects of the theory, especially university campuses, learning fields and job positions, are less understood and regarded as less important. Because the environment might be regarded as a foundation utilizing interests this topic seems to be crucial yet paid little attention. This research also aims to fill the void found in this field of literature.

\subsection{Holland's Personality Types Theory}

The theoretical framework of the research and the measurement tools used were determined by Holland's personality theory (1997). This section outlines the general descriptions of Holland's personality theory, the assumptions and principles of the theory, contemporary contributions to Holland's theory and the ISCED classification system.

Holland's theory (1997) consists of a few basic ideas and components of a more complex structure of these ideas. Firstly; people can be categorized to the extent that they are similar to the one of six types (Realistic, Investigative, Artistic, Social, Enterprising, \& Conventional). People with high level of similarities to one of the types are more likely to demonstrate their personality traits and behaviors. Secondly; the environments where people live and work can be defined according to the model that resembles the six environmental models (The same names with the personality types). Finally; Matching people and environments may result in predictions based on knowledge of personality types and environmental models. These may include vocational preference, vocational commitment and achievement, educational preference and achievement, self-efficacy, susceptibility to social behavior and environmental exposure.

The similarities and relationships between the types can be shown on a hexagonal model. The closer the distance between the two types, the greater the relationship and similarity between them. For example, on the hexagonal model, the Realistic and the Investigative types are closer and their similarities are more when compared with the other types. On the contrary, the Realistic and Social types are far from each other and their relationship and similarities are relatively small (Holland, 1997).

\subsection{Environmental Models}

Individuals can be assessed based on their personality types, in a similar way environment also can be evaluated according to some hypothetically defined environmental models. Environmental modalities are determined by the environment in which majority of a certain population takes place. For example, a social environment is mostly made up of people of the social type. If the characteristics of a group of forming an environment is known, then the features in which this group will be formed can also be estimated. Certainly an office environment full of bureaucrats and an office environment full of engineers will be different from each other. Environmental models, like personality types, are also shaped by activities, beliefs, competences, perceptions and values. For this reason, there are very close relationships between them (Holland, 1997). It is not considered as necessary to repeat these characteristics of environmental models as they are the same as those of personality types.

In a research conducted by Smart, Feldman and Ethington (2006) it is stated that university faculty members in different academic fields create academic environments that are characterized by differentiated characteristics depending on the priorities and goals of the environment. 
Considering the first research sample of the Holland's (1997) theory is made up of university and high school students (Reardon \& Bertoch, 2011), it might be concluded that environmental characteristics in educational life are also distinguished as it is the case for working environments.

However, despite the large number of empirical evidences on Holland's model, there are also research findings that RIASEC (Realistic, Investigative, Artistic, Social, Enterprising, \& Conventional) types are not sufficiently comprehensive enough to meet the complexity of the business world (Armstrong, Allison, \& Rounds, 2008). In Holland's theory (1997), some of the characteristics of working life are multi-dimensional and composed of some subcomponents, while the types are extremely broad. For example, there are jobs that are run by realistic types, such as factories, as well as jobs that are performed in the open field (Einarsdottir, 2001). Parallel to these explanations, and according to Holland's theory, environmental models can also be defined in terms of their orientation to the professional activities performed by individuals. In other words, environmental models can be expressed by RIASEC letter codes just like personality types, making it possible to examine the interaction between individuals and a specific environmental model (Spokane \& Cruza-Guet, 2005).

\subsection{Data/Ideas, Things/People Dimensions in Holland's Model}

Dimensions that are presumed to exist on the basis of Holland's hexagonal structure have been classified by Prediger (1981) as a two-dimensional structure with Data/Ideas (D/I), Things/People (T/P) poles. Prediger (1981) added Holland's hexagonal model Data-Ideas (Entreprising, Conventional - Investigative, Artistic types) and Things-People (Social - Realistic types) dimensions. These ensuing dimensions reveal the differences between personality types. For example, in the Data pole of the Data-Idea dimension, Conventional and Enterprising types are more interested in activities such as information recording and filing in contrast with Investigative and Artistic types in the Ideas section. Enterprising and Social types, on the sociability dimension, are more likely to engage in activities involving interpersonal interaction than either the Realistic or the Investigative types (Armstrong, Day, McVay, \& Rounds, 2008; Rounds and Tracey, 1993).

\subsection{International Standard Classification of Education (ISCED)}

There are a number of problems with the measurement of education levels and the nature of the comparison of these measures. First of all, this can be a very complicated task because it eliminates the need to reconcile a wide range of educational systems with the same titles. So much so that this differentiation can change over time in the same country, let alone among the countries (Schröder \& Ganzeboom, 2013).

One of the most widely used classifications in this regard is the International Standard Classification of Education (ISCED) developed by United Nations Educational, Scientific and Cultural Organization (UNESCO, 2006). ISCED is a highly detailed and comprehensive classification system developed by Organization for Economic Co-operation and Development (OECD , 1999) designed to "establish a framework for the compilation, analysis and reporting of internationally comparable educational statistics".

The ISCED Classification was developed primarily to compile comparable statistics across countries. With this kind of comparison, it is aimed to create a basis for international reporting at least on "broad fields". ISCED was originally developed by UNESCO in the mid-1970s and since then had been revised three times. ISCED is a product of an international agreement and has been officially recognized by the member countries of the UNESCO General Conference. In the ISCED-2013 classification, there are 26 broad educational fields organized in 10 broad groups. The term "broad field" in ISCED refers to the broad field or branch of an education or accreditation program. Detailed areas (third hierarchical level in classification) are only used in higher education or vocational training (UNESCO, 2014). 


\section{Method}

In this research it is aimed to present a visual comparison of career orientations of college students using ISCED classification system and Holland's personality types. Relational screening model, which aims to investigate certain relationships with demographic variables and to collect data by administering questionnaires or scales or interviews to learn and identify certain characteristics of a group (Cohen, Manion, \& Morrison, 2007; Karasar, 2012) was used.

\subsection{Sample}

The research was conducted on two separate samples. The first sample consisted of seven experts who are teaching staff working in the fields of education and Holland's theory and consulted with a structured interview form. For the second research sample a total of 529 university students (54.8\% female, $45.2 \%$ male) attending Hacettepe University were selected from 10 various higher education programs from each ISCED broad fields (see Table 1). It was decided to select the participants of this second sample from the sophomore and junior classes at the age of 18 and over, considering that the participants should facilitate the attributes such as success, continuity, and knowledge of the chosen major. Senior classes are left out of the research since they may tend to have concerns such as finding a job and answer the questionnaires accordingly. It has been decided that the number of participants to be included in the research sample from each educational program should be at least 50 with the assumption that the inter-variable analyzes are performed with parametric tests at the level of higher reliability of the group comparisons.

Table 1: Educational Programs of the Research Sample and Their Equivalents in ISCED 2013

\begin{tabular}{|c|c|c|c|c|}
\hline $\begin{array}{l}\text { ISCED Broad } \\
\text { field code }\end{array}$ & Broad field & Faculty & Educational Program & $\mathbf{n}$ \\
\hline 01 & Education & Education & Science Education & 53 \\
\hline 02 & Arts and humanities & Literature & German Language and Literature & 54 \\
\hline 03 & $\begin{array}{l}\text { Social sciences, journalism } \\
\text { and information }\end{array}$ & Education & $\begin{array}{l}\text { Psychological Counseling and } \\
\text { Guidance }\end{array}$ & 60 \\
\hline 04 & $\begin{array}{l}\text { Business, administration and } \\
\text { law }\end{array}$ & Law & Law & 50 \\
\hline 05 & $\begin{array}{l}\text { Natural sciences, } \\
\text { mathematics and statistics }\end{array}$ & Science & Math & 51 \\
\hline 06 & $\begin{array}{l}\text { Information and } \\
\text { Communication } \\
\text { Technologies }\end{array}$ & Education & $\begin{array}{l}\text { Computer and Instructional } \\
\text { Technology Education }\end{array}$ & 51 \\
\hline 07 & $\begin{array}{l}\text { Engineering, manufacturing } \\
\text { and construction }\end{array}$ & Engineering & Electrical engineering & 53 \\
\hline 08 & $\begin{array}{l}\text { Agriculture, forestry, } \\
\text { fisheries and veterinary }\end{array}$ & Engineering & Food Engineering & 55 \\
\hline 09 & Health and welfare & Health Sciences & $\begin{array}{l}\text { Physical Therapy and } \\
\text { Rehabilitation }\end{array}$ & 51 \\
\hline 10 & Services & $\begin{array}{l}\text { Economics \& } \\
\text { Administrative } \\
\text { Science }\end{array}$ & Family and Consumer Sciences & 51 \\
\hline
\end{tabular}

$(n=529)$

\subsection{Instruments}

A personal information form developed by the researcher and the Personal Globe Inventory-Short Form (PGI-SF) developed by Tracey (2010) and adapted to Turkish by Vardarlı (2014) were used to collect data in the research.

\subsubsection{Personal Globe Inventory Short Form}

Personal Globe Inventory (PGI) is an interest inventory developed by Tracey and Rounds (2002). Researchers have developed a three-dimensional inventory of interest to measure individuals' core 
interests, competence expectations and vocational preferences. In order to facilitate the use of inventory Tracey (2010) developed a short form (PGI-SF) with a total of 80 items, 40 of which are used to measure perceived abilities and 40 items for measuring interests. Short form of the PGI showed high validity and reliability values in the American sample. Based on the findings obtained in the development of the inventory, the researchers stated that PGI-SF was free of bias and did not produce different results in terms of gender and ethnicity. The Cronbach's alpha reliability coefficient in the long form of the inventory was .90 , while the reliability coefficient in the short form was .89 .

PGI-SF was adapted to Turkish by Vardarlı (2014) and applied to high school $(\mathrm{n}=605)$ and university students $(n=359)$ in İzmir, Turkey. To examine the cultural validity of PGI-SF a randomization test was conducted and CI and $\mathrm{p}$ values obtained are interpreted as it indicates a good fit with the complex circular pattern of inventory. RIASEC scores similarly have also been found to be in congruence with a complex circular model. Also subscale scores of Self-Evaluation Inventory (Kuzgun, 2003) and PGI-SF subscales correlations obtained were in the expected direction.

\subsubsection{Personal Information Form}

A standardized form was developed by the researcher to collect expert opinions. Three of the RIASEC letter codes, which represent the narrow educational fields of ISCED 2013 basic education and training the most, are expected to be chosen by the consulted experts. In the form, a sample application is given along with the directive. In addition, detailed information about Holland personality types is presented in order to guide the experts and to form concept union.

\subsection{Data Analysis}

In line with the opinions received from the experts, 26 ISCED educational fields have been located on a two-dimensional space (T/P - D/I) in accordance with their required interests and competences. Using the PGI-SF data collected from the second research sample, the positions of the undergraduate programs on the map were determined by multidimensional scaling (MDS) method. The mean scores of the T/P - D/I dimensions were converted to the correlation matrix consisting of the standardized $\mathrm{z}$ scores and the Euclidean distances between the educational fields.

\section{Findings and Discussion}

\subsection{Findings of the First Research Sample and Discussion}

Using the data of the first research sample interest scores of the ISCED educational fields were tried to be shown on a coordinate plane. In order to provide this indication, the triple-letter codes specified by the participants for each ISCED field have been converted into T/P - D/I scores.

In the MDS findings of the first research sample, the stress value calculated according to the Kruskal stress formula was found to be 0.01510 for three-dimensional solution and 0.05808 for two-dimensional solution. The value of $\mathrm{R}^{2}$ obtained shows that the explained variance of change according to the stress value reveals $99.9 \%\left(\mathrm{R}^{2}=.99890\right)$ for three-dimensional solution and $98.5 \%\left(\mathrm{R}^{2}=.98471\right)$ for two-dimensional solution. 
Table 2: Mean Scores of the T/P - D/I Dimensions of the First Research Sample

\begin{tabular}{|c|c|c|c|}
\hline $\begin{array}{l}\text { ISCED Broad } \\
\text { field code }\end{array}$ & ISCED Narrow field of education & $\begin{array}{l}\text { Dimension-1 } \\
\text { Things/People }\end{array}$ & $\begin{array}{c}\text { Dimension -2 } \\
\text { Data/Ideas }\end{array}$ \\
\hline 11 & Education & 1.6943 & -.4140 \\
\hline 21 & Arts & 1.6497 & .0208 \\
\hline 22 & Humanities (except languages) & .6713 & .9836 \\
\hline 23 & Languages & 1.2958 & -.0058 \\
\hline 31 & Social and behavioural sciences & 1.4826 & -.4131 \\
\hline 32 & Journalism and information & .2846 & .9805 \\
\hline 41 & Business and administration & -.0360 & -2.2975 \\
\hline 42 & Law & .4208 & -1.4482 \\
\hline 51 & Biological and related sciences & -.1511 & 1.3223 \\
\hline 52 & Environment & -1.1665 & .4031 \\
\hline 53 & Physical sciences & -.2181 & 1.2828 \\
\hline 54 & Mathematics and statistics & -.8967 & .5228 \\
\hline 61 & $\begin{array}{l}\text { Information and Communication } \\
\text { Technologies (ICTs) }\end{array}$ & .1970 & 1.2933 \\
\hline 71 & Engineering and engineering trades & -.7366 & .9100 \\
\hline 72 & Manufacturing and processing & -1.2713 & -.2167 \\
\hline 73 & Architecture and construction & .4381 & 1.0933 \\
\hline 81 & Agriculture & -1.3208 & -.5692 \\
\hline 82 & Forestry & -1.3977 & -.6088 \\
\hline 83 & Fisheries & -1.2717 & .1398 \\
\hline 84 & Veterinary & -.4056 & 1.0512 \\
\hline 91 & Health & .7437 & 1.1210 \\
\hline 92 & Welfare & 1.5666 & -.7537 \\
\hline 101 & Personal services & .9019 & -1.2760 \\
\hline 102 & $\begin{array}{l}\text { Hygiene and occupational health } \\
\text { services }\end{array}$ & -.5657 & -1.0602 \\
\hline 103 & Security services & -.9957 & -.9618 \\
\hline 104 & Transport services & -.9131 & -1.0993 \\
\hline
\end{tabular}

Using MDS does not aim to reduce the stress value of the application to zero. It is aimed at obtaining a balance in terms of interpretability (with a stress value just as low as a competence) (Hout, Papesh, \& Goldinger, 2015). With this point of view, a two-dimensional solution has been preferred to the interprete the educational fields in this research. Table 2 shows the values of the dimensions found in the two-dimensional MDS analysis.

After the distances between disparities were found to be in a linear relationship, distances between the variables and their proximity were investigated in a two dimensional space representation (see Figure 1). 


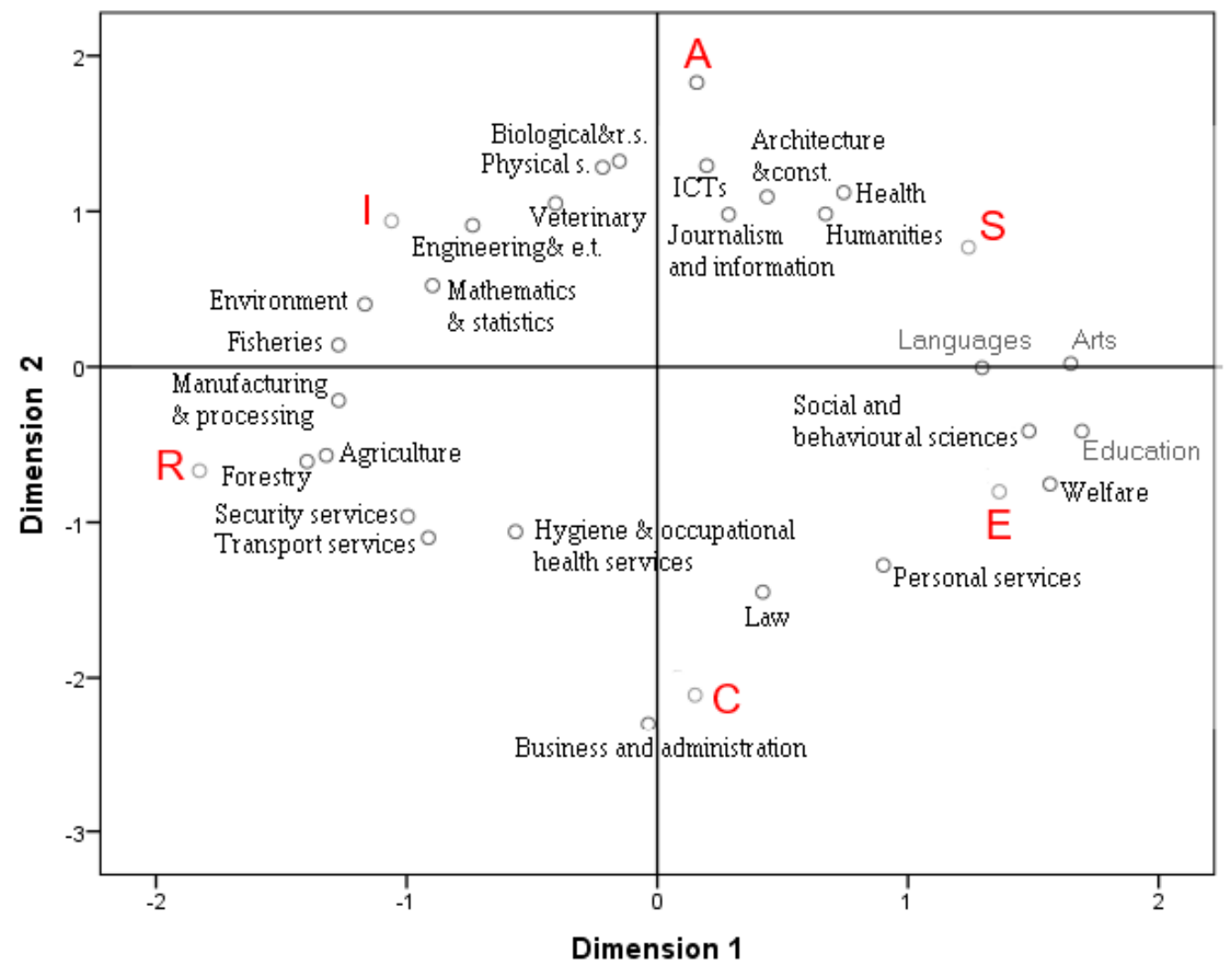

Figure 1. T/P - D / I Euclidean Distance Model Locations of ISCED Educational Fields

When Figure 1 is examined, it appears that in the Things pole there are educational fields such as forestry, agriculture, fishery products, engineering and mathematics where usually objects are used. Contrary to this, in the People's pole, there are educational fields such as education, social work and behavioral sciences which include activities such as informing, motivation and education in accordance with Prediger's (1981) explanations. Education fields on accounts, records and business processes such as business and management and law are included in the Ideas pole in the direction of the same explanations. Educational fields such as abstract subjects based on information, theories, biology involving working on concepts, physical sciences, information communication technologies, etc. are also in the Ideas pole that include these concepts as they are expected. In general, it is seen that educational fields are located in the appropriate regions in the D/I - T/P dimensions (see ACT, 2009; Armstrong, Deng \& Rounds, 2007; Prediger, 1981; Prediger \& Swaney, 2004).

Considering Holland's (1997) explanations of RIASEC types, it was seen that the educational fields were also in the appropriate regions for explaining the theoretical types. For example, in the Investigator type zone, which focuses on the investigation of observational, symbolic, systematic, physical, biological and cultural phenomena, appropriate exploration, mathematics and veterinary fields are located in these explanations. In the findings, a number of incompatible conclusions with Holland's theory (1997) were reached. As we have seen in this research, nine of the 26 ISCED educational fields are located between Realistic and Conventional types, and the distance between these two types is the highest distance when compared with the other types. This inconsistency with the theoretical structure may have been due to the disorder in the Conventional and Realistic types as indicated by Tracey and Rounds (1995) and Prediger or as Reardon and Bertoch (2011) have reported educational and academic environments may have limited options for these two personality types. 


\subsection{Findings of the Second Research Sample}

\subsubsection{Interests of College Students}

Based on the data obtained from the second research sample, locations of D/I - T/P dimensions were determined according to the mean interest scores of the educational programs and compared with the areas on a two dimensional solution (see Table 3).

Table 3: D/I - T/P Dimensions Mean Scores of the Second Research Sample

\begin{tabular}{clcc}
\hline $\boldsymbol{N r}$ & Educational Field & $\begin{array}{c}\text { Dimension-1 } \\
\text { Data/Ideas }\end{array}$ & $\begin{array}{c}\text { Dimension-2 } \\
\text { Things/People }\end{array}$ \\
\hline 1 & Family and Consumer Sciences & .8329 & .8210 \\
2 & German Language and Literature & -1.1973 & .7575 \\
3 & Computer and Instructional Technology & -.7931 & -.7067 \\
4 & Education & 1.4921 & -1.3282 \\
5 & Electrical engineering & -.6086 & .9026 \\
6 & Pcience Education & -.2737 & -1.0739 \\
7 & Food Engineering & -1.0561 & -.9710 \\
8 & Law & 1.0396 & .8270 \\
9 & Math & 1.8319 & .3178 \\
10 & Psychological Counseling and Guidance & -1.2677 & .4539 \\
\hline
\end{tabular}

The stress value calculated according to the Kruskal stress formula in the MDS findings of the second research sample's interests was found to be .01972 for three-dimensional solution and .12845 for two-dimensional solution. The value of $\mathrm{R}^{2}$ obtained explains $99.82 \%\left(\mathrm{R}^{2}=.9982\right)$ of the change for three-dimensional solution and $89.51 \%\left(\mathrm{R}^{2}=.8951\right)$ of the change for twodimensional solution according to the stress value. In the second research sample, a twodimensional representation was chosen for the same reasons explained in the first research sample findings section. The stress value obtained in two-dimensional display indicates poor fit according to criteria in related literature (see Hout, Papesh, \& Goldinger, 2015; Mead, 1992; Özdamar, 2004; Takane, Young, \& De Leeuw, 1977). Second research sample's interest scores about the distance and closeness between two variables in two-dimensional space were examined and this representation is presented in Figure 2. 


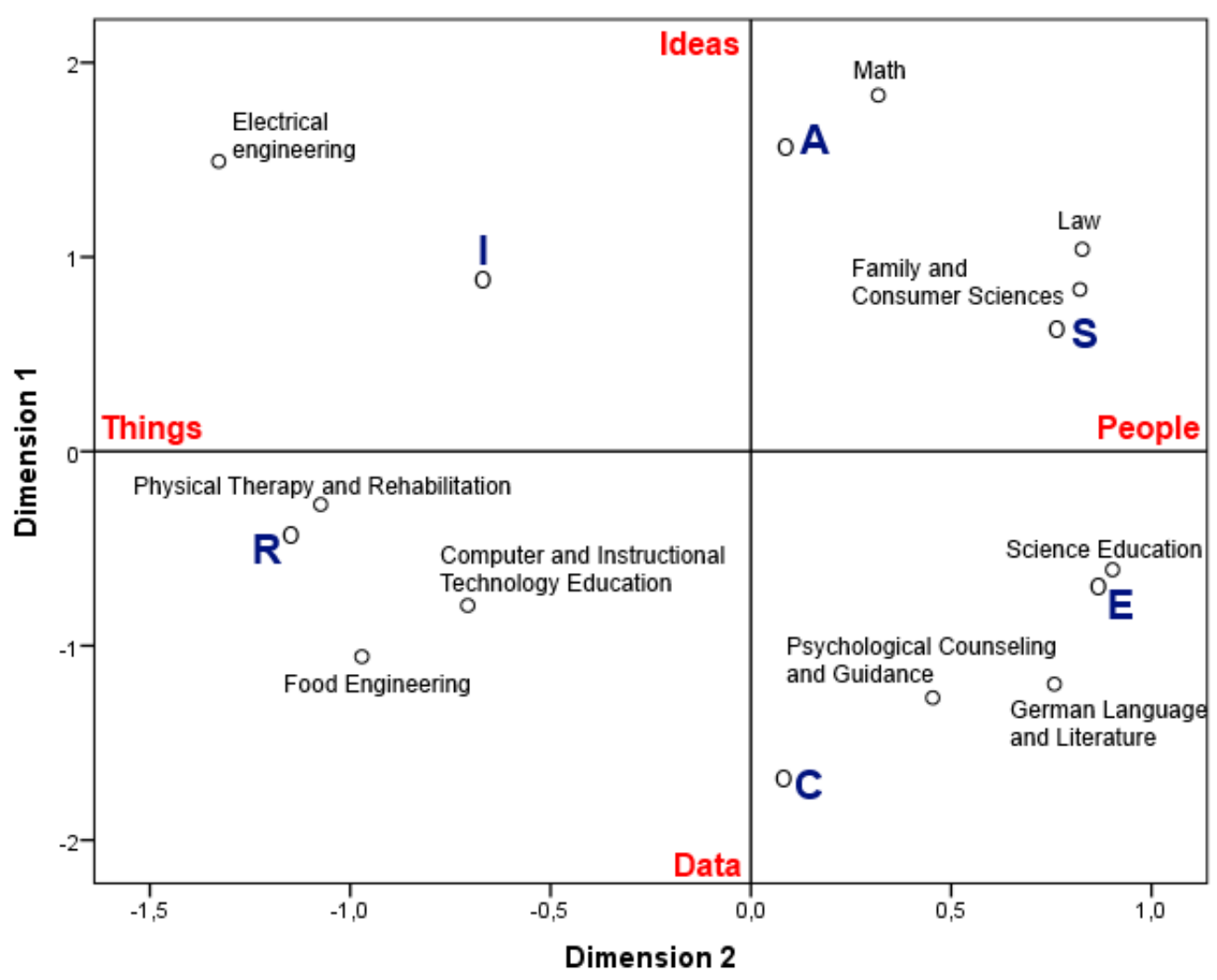

Figure 2. Relations of the Education Programs in the Second Research Sample in D/I - T/P Dimensions According to Euclidean Distance Model

Other than some inappropriate findings with the theoretical explanations in the positioning of the higher education programs in the $\mathrm{D} / \mathrm{I}-\mathrm{T} / \mathrm{P}$ dimensions, some of the programs' interest characteristics were found to be mismatching with their presumed environmental models. Tracey and Rounds (1995) and Prediger (2000) also report that the vague structure revealed by the Realistic and Conventional types in Holland's theory is apparent. Particularly positioning of Psychological Counseling and Guidance and Computer Education Technologies programs in Conventional and Realistic types regions does not match the theoretical explanations of Holland (1997). While Psychological Counseling and Guidance program is expected to be close to the Social type and the Computer Education Technologies program to the Investigative type, these programs are located closer to other relatively irrevelant types. These inconsistencies may also depend on factors that influence participants' selection of the tertiary program, other than limited work experience. Participants may have chosen their program utilizing their higher education entrance exam scores rather than considering their area of interest. Other factors, such as employment opportunities of the program, may also be considered as more important than their interests. For these reasons, one of the comprehensible interpretations that can be brought to this research sample findings is that college students do not make choices according to their interests while selecting a higher education program.

\subsubsection{Competence Beliefs of College Students}

Based on the data obtained from the second research sample, D/I - T/P dimensions were determined according to participants' from 10 educational programs mean scores of competence beliefs (see Table 4). 
Table 4: D/I - T/P Dimensions Competence Beliefs Mean Scores of the Second Research Sample

\begin{tabular}{clcc}
\hline $\boldsymbol{N} \boldsymbol{r}$ & Educational program & $\begin{array}{c}\text { Dimension-1 } \\
\text { Data/Ideas }\end{array}$ & $\begin{array}{c}\text { Dimension-2 } \\
\text { Things/People }\end{array}$ \\
\hline 1 & Family and Consumer Sciences & .4124 & 1.1662 \\
2 & German Language and Literature & -1.8270 & -.6988 \\
3 & Computer and Instructional Technology & .4090 & 1.1811 \\
4 & Education & 1.2594 & -1.0634 \\
5 & Electrical engineering & -.8474 & .5743 \\
6 & Pcience Education & .6885 & .7813 \\
7 & Food Engineering & -1.1521 & -.8419 \\
8 & Law & .9925 & -.0640 \\
9 & Math & 1.3748 & -1.2469 \\
10 & Psychological Counseling and Guidance & -1.3102 & .2122 \\
\hline
\end{tabular}

The stress value calculated according to the Kruskal stress formula in the MDS findings applied to the competence beliefs scores of the second research sample was found to be .01527 for threedimensional solution and ,16945 for two-dimensional solution. The value of $\mathrm{R}^{2}$ obtained explained $99.8 \%\left(\mathrm{R}^{2}=.99852\right)$ of three-dimensional solution and $89.5 \%\left(\mathrm{R}^{2}=.83863\right)$ of two dimensional solution according to the stress value. For the second research sample's competence beliefs data a two-dimensional representation is preferred for the same reasons explained above. Stress value obtained in two-dimensional display indicated poor fit (see Hout, Papesh, \& Goldinger, 2015; Mead, 1992; Özdamar, 2004; Takane, Young, \& De Leeuw, 1977). Twodimensional representation of the distance between the competence beliefs scores of the second research sample were investigated and this representation is presented in Figure 3.

When examining the competence beliefs of the educational programs in the second research sample using D/I - T/P poles, significant differences are noticed according to participants' interests. For example, mathematics program is closer to the Investigative type in terms of competence beliefs while it is close to the Artistic type in terms of interests. It is seen that the activities in the mathematics program are based on the activities that are related with the use of creativity, but the activities they perform are mostly the activities of the Investigative type. This differential between interests and competence beliefs shows that there is not a single factor effecting major selection in higher education and that all of the relevant factors must be evaluated together. 


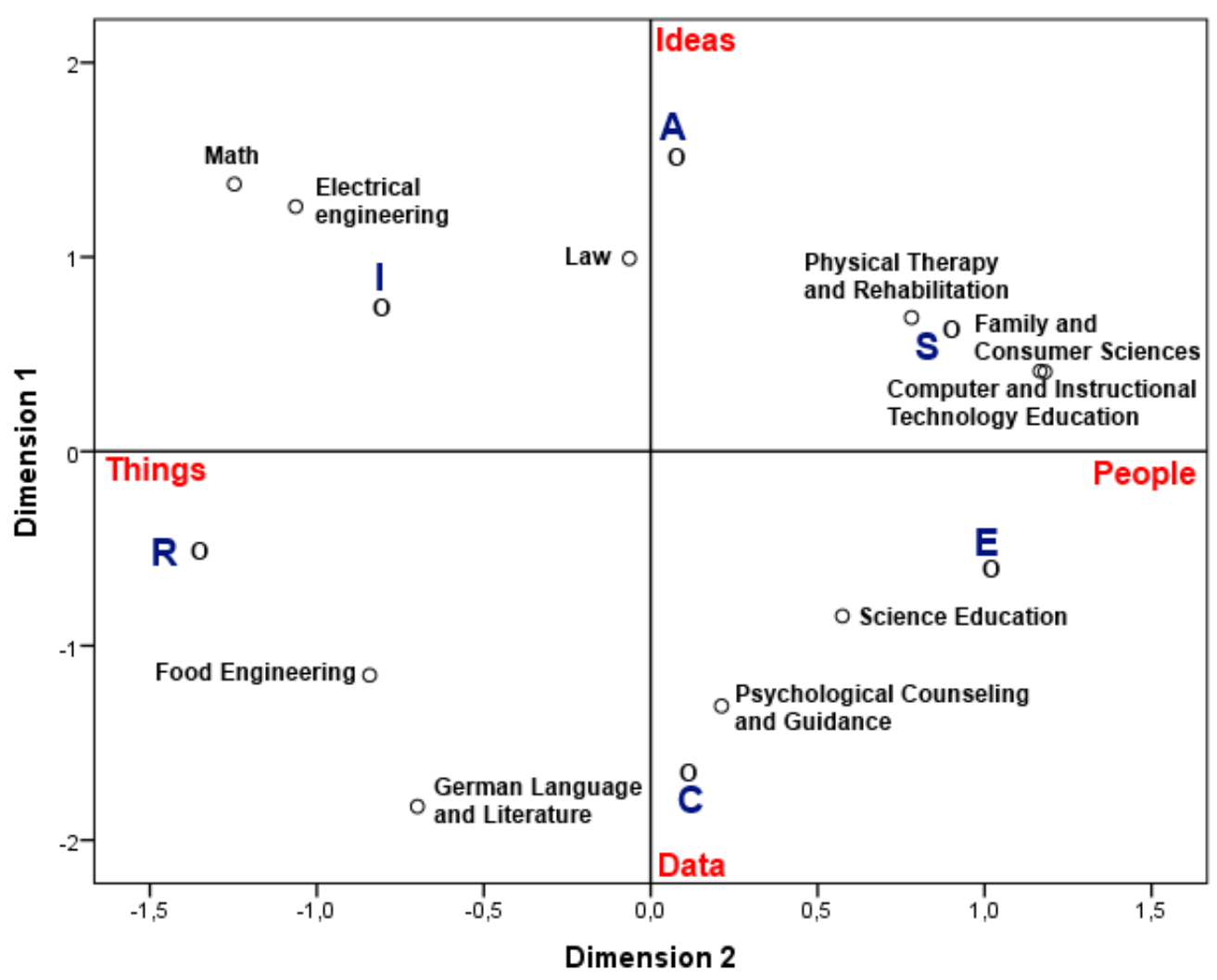

Figure 3. Competence Beliefs of the Educational Programs in Second Research Sample Using D/I - T/P Poles According to Euclidean Distance Model

\section{Conclusion}

There are many researches related to Holland's personality types theory, the measurement tools developed on the basis of this theory and the hexagonal structure pointed out by theory, but research on the conceptualization of environmental models remains limited (Spokane \& CruzaGuet, 2005). With this research, the environmental characteristics of the ISCED broad fields in relation with the interest areas and competence beliefs have been revealed in order to serve as a guide to the career counselors who will assist the clients while choosing a higher education program in the future. At the end of the research, a visual representation including the core education and training fields of ISCED-2013 classification system is described which might be helpful when Holland's theory (1997) based measurement tools used during the transition to higher education.

Educational fields are found to be characterized by their general characteristics, including interests and competence beliefs, and are located in regions consistent with Prediger's D/I - T/P dimensions and Holland's RIASEC typology explanations to a certain extent. However, particularly in Conventional and Realistic type regions, some of these positions have been found to be incongruous, and this finding might be a result of relatively broad structural definition of RIASEC and ISCED education fields. With the data of the second research sample, in which it was investigated if the actual state reflects the ideal state or not in terms of both interests and competence beliefs, two-dimensional representation showed a poor fit and inadequate positioning which is not in accordance with the theoretical explanations. It is concluded that, currently interests and competence beliefs are not the key considerations for students when choosing a higher education program and the current environmental models partly correspond with their respective theoretical explanations. 
Some other suggestions especially for field practitioners may be presented, which point out the results of this study. The findings of the research point to the mismatch between college students' interests and abilities and the program they are in. This differentiation between interests and perceived skills shows that a single feature (eg entrance exam score) is not sufficient in the selection of programs in higher education, and all relevant factors should be evaluated together. For this reason, it is beneficial to consider other characteristics (interests, values, etc.) of the candidates by psychological counselors.

Another suggestion can be considered regarding the interpretation of the scores of interest inventories. Determining an environmental model such as ISCED in this study in directing to the selection of the area on a visual structure can help the clients to make more accurate decisions. With this in mind, while evaluating the results obtained from clients' interest inventories, instead of directing the client to a definite or single program or profession, it may be more beneficial to use broader vocational fields as they were mapped in this research

This study also has some important limitations. First of all, there are many factors that may affect vocational choices, as well as some participant characteristics that may affect the findings of this research. As reported, characteristics of the sample may also lead to differentiation in Holland's RIASEC structure (Rounds and Tracey, 1993). Although the parameters such as college entrance year and grade level are important to affect the findings, such data collected in the study were excluded from the scope of the research because they were not in a sufficient number to demonstrate the generalizability of these variables. For this reason, these research results should be used cautiously especially considering that grade level can affect the differentiation of students' interests and abilities.

\section{References}

Akkök, F., \& Watts, T. G. (2006). Mesleki Bilgi, Rehberlik ve Danışmanlık Hizmetleri Türkiye Ülke Raporu. Ankara: İSKUUR Dökümanları.

Armstrong, P.I., Allison, \& W. Rounds, J. (2008). Development and initial validation of brief public domain RIASEC marker scales. Journal of Vocational Behaviour, 73, 287-299. doi: 10.1016/j.jvb.2008.06.003

Armstrong, P.I., Day, S.X., McVay, J.P., \& Rounds, J. (2008). Holland's RIASEC model as an integrative framework for individual differences. Journal of Counseling Psychology, 55(1), 1-18. doi: 0.1037/0022-0167.55.1.1

Armstrong, P.I., Deng, C. P., \& Rounds, J. (2007). The fit of Holland's RIASEC model to US occupations. Journal of Vocational Behavior, 71(1), 1-22. doi: 10.1016/j.jvb.2007.04.002

Cohen, L., Manion, L., \& Morrison, K. (2007). Research methods in education (6th. Ed.). NY: Routledge.

Devlet Planlama Teşkilatı (DPT). (2014). Onuncu Kalkınma Planı (2014-2018). www.resmigazete.gov.tr/eskiler/2013/07/20130706M1-1-1.doc. Accessed 14 May 2018.

Einarsdottir, S. (2001). Structural equivalence of vocational interests across culture and gender: Differential item functioning in the Strong Interest Inventory (Unpublished Doctoral dissertation). University of Illinois, Illinois. http://hdl.handle.net/2142/79622. Accessed 19 July 2018. 
European Union. (2011). Lifelong guidance across Europe: reviewing policy progress and future prospects. www.cedefop.europa.eu/files/6111_en.pdf. Accessed 18 May 2018.

Feldman, K.A., Ethington, C. A., \& Smart, J.C. (2001). A further investigation of major fields and person-environment fit: Sociological vs. psychological interpretations of Holland. Journal of Higher Education, 72, 670-698. doi: 10.2307/2672899

Holland, J. L. (1974). Vocational guidance for everyone. Educational Researcher, 3(1), 9-15. https://files.eric.ed.gov/fulltext/ED086926.pdf. Accessed 19 July 2018.

Holland, J.L. (1996). Exploring careers with a typology: What we have learned and some new directions. American Psychologist, 51, 397-406. doi: 10.1037/0003-066X.51.4.397

Holland, J.L. (1997). Making vocational choices; A theory of vocational personalities and work environments (3rd ed.). Florida: PAR Inc.

Hout, M. C., Papesh, M.H., \& Goldinger, S.D. (2013). Multidimensional scaling. Wiley Interdisciplinary Review of Cognitive Sciences, 4(1), 93-103. doi: 10.1002/wcs.1203

Karasar, N. (2012). Bilimsel araştırma yöntemleri: Kavramlar-ilkeler- teknikler. (23th Ed.). Ankara: Nobel.

Kuzgun, Y. (2003). Kendini Değerlendirme Envanteri El Kitabı. Ankara: ÖSYM Yayınları.

Mead, A. (1992). Review of the development of multidimensional scaling methods. The Statistician, 41(1), 27-39. doi: 10.2307/2348634

Miller, M. J. (1994). A "circuitous" test of Holland's theory. Journal of Employment Counseling, 31, 137-143. doi: 10.1002/j.2161-1920.1994.tb00183.x

Miller, S. M. (2010). The validity of the Strong Interest Inventory in predicting college major choice and academic achievement (Unpublished doctoral dissertation). Washington State University College of Education, Washington. http://hdl.handle.net/2376/2818. Accessed 19 July 2018.

Organisation for Economic Co-operation and Development. (1999). Classifying educational programmes. manual for ISCED-97. Implementation in OECD Countries. 1999 Edition. Paris: OECD Publications Service. http://www.oecd.org/education/skills-beyondschool/1962350.pdf. Accessed 19 July 2018.

Özdamar K. (2004). Paket programlar ile istatistiksel veri analizi (5. Baskı). Eskişehir: Kaan Kitabevi.

Özyürek, R. (2013). Kariyer psikolojik danışmanlı̆̆ kuramları: Çocuk ve ergenler için kariyer rehberliği uygulamaları. Ankara: Nobel Akademi.

Porter, S. R., \& Umbach, P.D. (2006). College major choice: An analysis of person-environment fit. A Research in Higher Education, 47(4), 429-449. doi: 10.1007/s11162-005-9002-3

Prediger, D. J. (1981). Dimention underlying Holland's hexagon: Missing link between interest and occupations. Journal of Vocational Behavior, 21, 259-287. doi: 10.1016/00018791(82)90036-7

Prediger, D. J. (2000). Holland's hexagon is alive and well - Though somewhat out of shape: Response to Tinsley. Journal of Vocational Behavior, 56(2), 197-204. doi: 10.1006/jvbe.1999.1737

Prediger, D.J., \& Swaney, K.B. (2004). Work task dimensions underlying the world of work: Research results for diverse occupational databases. Journal of Career Assessment, 12(4), 440-459. doi: 10.1177/1069072704267737

Reardon, R.C., \& Bertoch S.C. (2011). Revitalizing educational counseling: How career theory can inform a forgotten practice. The Professional Counselor: Research and Practice, 1(2), 106-121. doi: 10.15241/rcr.1.2.109

Rounds, J., \& Tracey, T.J. (1993). Prediger's dimensional representation of Holland's RIASEC circumplex. Journal of Applied Psychology, 78 (6), 875-890. doi: 10.1037/00219010.78.6.875

Schröder, H., \& Ganzeboom, H. B. (2013). Measuring and modelling level of education in European societies. European Sociological Review, 30(1), 119-36. doi: 10.1093/esr/jct026

Smart, J. C., Feldman, K. A., \& Ethington, C. A. (2006). Holland's theory and patterns of college student success (Commissioned Report for the National Symposium on Postsecondary 
Student Success: Spearheading a Dialog on Student Success). Washington, DC: National Postsecondary Education https://nces.ed.gov/npec/pdf/Smart_Team_Report.pdf. Accessed 19 July 2018.

Cooperative.

Spokane, A.R. \& Cruza-Guet, M.C. (2005). Holland's theory of vocational personalities in work environments. In S.D. Brown \& R.W. Lent (Eds.). Career development and counseling: Putting theory and research to work (pp. 24-41). N.J.: John Wiley ve Sons.

Takane, Y., Young, F. W., \& De Leeuw, J. (1977). Nonmetric individual differences multidimensional scaling: An alternating least squares method with optimal scaling features. Psychometrika, 42(1), 7-67. doi: 10.1007/BF02293745

Tracey, T.J.G. (2010). Development of an abbreviated Personal Globe Inventory using item response theory: The PGI-Short. Journal of Vocational Behavior, 76(1), 1-15. doi: 10.1016/j.jvb.2009.06.007

Tracey, T.J.G. (2002). Personal Globe Inventory: Measurement of the spherical model of interests and competence beliefs. Journal of Vocational Behaviour, 60, 113-172. doi: $10.1006 /$ jvbe. 2001.1817

Tracey, T.J.G., \& Gupta, S. (2008). Interest assessment in an international context. J.A. Athanasou ve R. Van Esbroeck (Ed.). International handbook of career guidance (pp. 52537). Netherlands: Springer Science and Business Media B.V.

Tracey, T.J.G., \& Robbins S.B. (2006). The interest-major congruence and college success relation: A longitudinal study. Journal of Vocational Behavior, 69(1), 64-89. doi: 10.1016/j.jvb.2005.11.003

Tracey, T.J.G., \& Rounds, J. (1995). The arbitrary nature of Holland's RIASEC types: A concentric-circles structure. Journal of Counseling Psychology, 42 (4), 431-439. doi: 10.1037/0022-0167.42.4.431

United Nations Educational, Scientific and Cultural Organization. (2006). ISCED 1997: International Standard Classification of Education. May 2006 Re-edition. www.uis.unesco.org/Library/Documents/isced97-en.pdf. Accessed 14 May 2018.

United Nations Educational, Scientific and Cultural Organization. (2014). ISCED Fields of education and training 2013 (ISCED-F 2013). http://www.uis.unesco.org/Education/Documents/isced-fields-of-education-training2013.pdf. Accessed 10 May 2018.

Vardarlı, B. (2014). Küresel model bağlamında mesleki ilgilerin Türkiye'deki yapısının incelenmesi: İzmir ili örneği (Unpublished Masters Thesis). Ege University Social Sciences Institute, İzmir.

World Bank (2015). Country Program Snapshot. http://www.worldbank.org/content/dam/Worldbank/document/eca/Turkey-Snapshot.pdf. Accessed 14 May 2018. 